\title{
Morphological signs of connective tissue dysplasia as predictors of frequent post- exercise musculoskeletal disorders
}

\author{
V. N. Nikolenko ${ }^{1,2}$, M. V. Oganesyan', A. D. Vovkogon ${ }^{1,3}$, Yu Cao ${ }^{1}$, A. A. Churganova', M. A. Zolotareva', \\ E. E. Achkasov ${ }^{1}$, M. V. Sankova ${ }^{1}$, N. A. Rizaeva ${ }^{1}$ and M. Y. Sinelnikov ${ }^{4^{*}}$ (i)
}

\begin{abstract}
Background: Connective tissue dysplasia (CTD) is a risk factor for musculoskeletal disorders. Changes caused by disorganization of collagen and elastin fibers lead to the inability of withstanding heavy mechanical stress. In clinical practice, diagnosis of these disorders depends on physical and anthropomorphic evaluation.

Methods: Forty-eight patients with frequent post-exercise musculoskeletal disorders were evaluated for CTD. The control group included 36 healthy participants. Both groups were evaluated via therapeutic examination with assessment of anthropometric indicators and physical-physiological evaluation, surveying and gathering of anamnesis. Based on testing results, study participants were evaluated on CTD presence and risk factors.

Results: All experimental group patients had connective tissue dysplasia of moderate and severe degree, with a total score of $49.44 \pm 13.1$. Certain morphological characteristics showed prevalence, allowing to determine pathognomonic predictors of high predisposition to frequent post-exercise musculoskeletal disorders. Back pain (100\%), asthenic syndrome and kyphotic spinal deformation (75\%), high gothic palate, hypermobility of joints and the auricles, excessive elasticity (63\%), varicose veins of the lower extremities (56\%) and hemorrhoids (56\%), changes in the shape of the legs and temporomandibular joint (50\%) showed to be significant clinical factors indicating possible connective tissue dysplasia.

Conclusions: The presence of these diagnostically significant morphological signs of CTD in humans is a pathognomonic predictor of a high predisposition to frequent injuries. Their early detection helps promote proper appointment of adequate physical activity regimen and develop treatment for the underlying cause.
\end{abstract}

Keywords: Post-exercise musculoskeletal disorders, Connective tissue dysplasia, Morphological predictors

\section{Background}

Physical exercise is one of the main components of a healthy lifestyle. Recently, there has been an increase in the number of musculoskeletal disorders during physical training [1] and in the number of patients with

\footnotetext{
*Correspondence: rektorat@sechenov.ru; expedition@mma.ru;

Mikhail.y.sinelnikov@gmail.com

${ }^{4}$ Institute for Regenerative Medicine, Sechenov University, st. Trubetskaya, 8, bld. 2, 119991 Moscow, Russia

Full list of author information is available at the end of the article
}

characteristic morphological signs of connective tissue dysplasia (CTD) [2-4]. CTD manifestation is due to inherited mutations of genes encoding the synthesis and spatial organization of collagen, structural proteins and proteincarbohydrate complexes, enzymes and their co-factors [26]. At the same time, adverse environmental factors play an important role in clinical manifestation of this condition $[7,8]$. The combination of these factors leads to pathological change in elastin and collagen fibers facilitating significant restructuration of connective tissue of

(c) The Author(s). 2020 Open Access This article is licensed under a Creative Commons Attribution 4.0 International License, which permits use, sharing, adaptation, distribution and reproduction in any medium or format, as long as you give appropriate credit to the original author(s) and the source, provide a link to the Creative Commons licence, and indicate if changes were made. The images or other third party material in this article are included in the article's Creative Commons licence, unless indicated otherwise in a credit line to the material. If material is not included in the article's Creative Commons licence and your intended use is not permitted by statutory regulation or exceeds the permitted use, you will need to obtain permission directly from the copyright holder. To view a copy of this licence, visit http://creativecommons.org/licenses/by/4.0/ The Creative Commons Public Domain Dedication waiver (http://creativecommons.org/publicdomain/zero/1.0/) applies to the data made available in this article, unless otherwise stated in a credit line to the data. 
different severity [9], which determines the large spectrum of CTD morphological manifestations [10-15]. According to existing studies, CTD is quite common, reaching an incidence of up to $85.4 \%$ in some populations $[16,17]$.

CTD is characterized by a variety of clinical manifestations - from subclinical forms to polysystemic pathology $[18,19]$. The classification of external and internal morphological signs of CTD has been unified [20, 21]. The combination of morphological signs is so variable that it is often difficult to integrate many individual symptoms and properly diagnose CTD [10]. Clinical interest in CTD has significantly increased largely due to the aggravating effects of this disorder on the course of almost all diseases [22]. Patients with CTD are observed by different specialists, each of whom prescribes his own treatment, which in many cases is untimely and often ineffective [23]. CTD should be considered in patients with frequent post-exercise musculoskeletal disorders, as hypersensitivity to physical exercise and predisposition to repeated injuries is a characteristic symptom of this condition [24]. It is therefore relevant to analyze the presence of morphological signs of CTD in patients with frequent post-exercise musculoskeletal disorders and injuries to determine the best course of action for prevention and treatment. In this study we assess the prevalence of morphological signs of CTD in individuals with frequent post-exercise musculoskeletal disorders in order to develop additional therapeutic-preventive measures and recommendations for choice of adequate physical activity regimen.

\section{Material and methods Participant selection}

A total of 84 student and faculty volunteers form Sechenov University were included in this clinical and anthropological study, conducted in accordance to STROBE guidelines. All participants were recruited on a volunteer basis from Sechenov University, and were engaged in amateur (non-professional) running sport (track, treadmill exercises). The specter of recurrent injuries of the musculoskeletal system included ligament spraining, ruptures, joint subluxations or dislocation, which occurred during regular exercise. The subjects were split into two groups according to their state of physical health and incidence of frequent post-exercise musculoskeletal disorders. Group 1 (experimental group) included 48 subjects aged from 18 to 47 years old (average $36.38 \pm 6.02$ years) with frequent post-exercise musculoskeletal disorders. Group 2 (control group) was represented by 36 healthy participants, aged $18.85 \pm 0.56$ years, not showing any signs of post-exercise musculoskeletal disfunction.

\section{Clinical and anthropomorphic evaluation}

All participants completed a questionnaire aimed to assess the state of connective tissue dysfunction, with analysis of all 66 morphological signs of CTD [25-27] and underwent therapeutic evaluation. Therapeutic evaluation included assessment of anthropometric indicators, such as body weight, height, arm span, chest volume, facial length and zygomatic width, length of the hand and its middle finger, the height of the lower and upper body segments and foot length. A facial index was also calculated to identify a narrow facial skeleton. Anthropomorphic proportionality was evaluated using the Verveka and Pigne indexes. The Varga and Quetelet indexes were calculated to assess body weight. Dolichostenomelia was diagnosed by the ratio of the hand and foot lengths to height, by the ratio of arm span to height, and by the ratio of the upper body segment to the lower segment. The thumb and wrist tests were performed to diagnose arachnodactyly. Hypermobility of the joints was evaluated according to Bayton's criteria [28, 29]. Concomitant pathology of internal organs was diagnosed with ultrasound scanning, fibrogastroduodenoscopy and $\mathrm{X}$-ray evaluation. Blood pressure and heart rate were documented.

\section{Ranking clinical significance of symptoms and CTD diagnosis}

The most common symptoms were ranked according to their clinical significance based on the scale of Kadurina T.I. and Abbamukova L.N [21].. The Karudina-Abbamukova scale rates each CTD sign on a scale of 0-4 points. A total score of under 20 is characteristic of no CTD. CTD of average severity is diagnosed with a score of 21 to 40 points, and severe CTD with 41 points and more.

\section{Statistical analysis}

The significances of differences between Group and Group 2 were determined using the independent t-test or the nonparametric Mann-Whitney U-test when variables were non-normally distributed. Anthropomorphic findings and rates of injury were compared using Pearson's chi-squared test or Fisher's exact test. The minimal number of subjects that needed to be enrolled in this study was calculated using power analyis. Statistical dada was calculated using RStudio software, version 1.2.1335 (RStudio, Inc., Boston, MA, USA). Results are presented as means \pm standard deviation or as numbers and percentages, and statistical significance was set at $P$ values $<0.05$.

\section{Results}

The minimal size sample for both groups for our dichotomous endpoint, two independent sample study (power $90 \%$, alpha 0.05 ) was 14 . The asthenic constitutional type 
was more common in Group 1. Deficit of body weight (Quetelet index $\leq 25$ ) was more common in Group 1 $(p<0.05)$. Subjects in Group 1 more often had disproportionately long hands and feet in comparison with Group $2(p<0.05)$ (Table 1). Arachnodactyly, diagnosed by positive wrist and thumb tests was significantly more common in subjects with frequent muscular-skeletal disorders than in the control group (Table 2).

Kyphotic spinal deformation with asymmetry of shoulders, shoulder blades and pelvic bones, chest deformity, flat foot combined with valgus installation, macrodactyly of the first toe significantly prevailed in Group $1(p<$ $0.05)$. Back pain was present in all subjects in Group 1. The hypermobility syndrome, characterized by joint instability, "crunches" and pain during movement, repeated joint dislocations and subluxations, accompanied by ligament sprains and ruptures was common in Group 1 subjects. Subjects in Group 1 had a narrow facial skeleton, malocclusion and a high gothic palate (Table 3).

Keloid scars and hemorrhagic syndrome (petechiae), hyperpigmentation along the spinous processes, atrophic skin striae, and telangiectasia were more common Group $1(p<0.05)$. Most in Group 1 had increased brittleness, softness in nails as well as disorders of the homogeneous structure of the nail plate $(p<0.05)$. Thin, brittle hair, areas of alopecia, auricles with excessive elasticity were common in Group $1(p<0.05)$. Patients in Group 1 showed significantly higher rates of muscular pathology (hypotrophy, muscle hypotension, diastasis of the rectus abdominis muscles and abdominal hernias) $(p<0.05)$ (Table 4).

Cardiovascular pathology (mitral valve prolapse, vascular dystonia, rate of tachycardia incidents, lower overall systolic pressure, varicose veins, hemorrhoids), ophthalmic manifestations (medium severity myopia) and gastrointestinal pathologies (biliary dyskinesia, failure of the stomach cardia and gastroesophageal reflux syndrome) were more common in Group 1 (Table 5).
Asthenic syndrome (decreased working capacity, increased fatigue, sleepiness, general weakness, especially in the mornings) and pain were often observed in the patients with frequent post-exercise musculoskeletal disorders $(p<0.05)$.

The most common and diagnostically significant symptoms according to the Kadurina-Abbamukova scale [21] were kyphotic spinal deformation, myopia, asthenic syndrome and back pain. The total score of each individual patient in Group 2 was less than 20 points, which was not characteristic of CTD. Patients in Group 1 were diagnosed with medium severity CTD in $37.5 \%$ and severe CTD in $62.5 \%$ of cases. The total score of CTD signs in these patients was significantly higher $(49,44 \pm$ $13,1)$ compared to the control group $(11,33 \pm 3,29)$ (Table 6).

\section{Discussion}

All subjects with frequent post-exercise musculoskeletal disorders in this study were diagnosed with CTD. This underlines the overlooked significance of CTD in clinical medicine [30]. Such patients should observe a specific physical regimen with proper alternation of exercise and rest $[11,23]$. The necessity of adequate physical activity and training pace has long been established [31]. Patients with CTD are recommended to perform regular aerobic exercises 3 times a week for 40-60 min (swimming, walking, moderate running, cycling, badminton, bowling, table tennis). Patients with CTD have been advised no to partake in activities such as ballet, group sports associated with a high risk of injury and weightlifting $[18,23,32]$.

Our study was aimed at assessing the clinical and morphological signs which can suggest the presence of CTD in otherwise undiagnosed patients. Our results have shown that the asthenic constitutional type was a common morphological feature in patients with CTD. This phenomenon has been recognized by several population-

Table 1 The prevalence of the diagnostically significant body proportionality indexes and indexes on dolichostenomelia in individuals with frequent post-exercise musculoskeletal disorders in comparison with CG

\begin{tabular}{|c|c|c|c|}
\hline Index & $\begin{array}{l}\text { Diagnostic Values } \\
\text { of CTD }\end{array}$ & $\begin{array}{l}\text { Comparison group } \\
n=36\end{array}$ & $\begin{array}{l}\text { Persons with frequent post-exercise } \\
\text { musculoskeletal disorders } n=48\end{array}$ \\
\hline Quetelet Index & $\leq 25$ & $41,6 \pm 8,2 \%$ & $62,5 \pm 6,9 \%^{a}$ \\
\hline Vargi Index & $<1,7$ & $8,3 \pm 4,5 \%$ & $31,3 \pm 6,7 \%^{\mathrm{b}}$ \\
\hline Verveka Index & $1,26-1,35$ & $0 \%$ & $18,8 \pm 5,6 \%^{\mathrm{a}}$ \\
\hline Pigne Index & $\geq 30$ & $8,3 \pm 4,5 \%$ & $25,0 \pm 6,3 \%^{a}$ \\
\hline Arm swing/height & $\geq 1,05$ & $8,3 \pm 4,5 \%$ & $12,5 \pm 4,8 \%$ \\
\hline Upper/lower segment & $<0,86$ & $8,3 \pm 4,5 \%$ & $12,5 \pm 4,8 \%$ \\
\hline Foot length/height & $>15 \%$ & $0 \%$ & $31,3 \pm 6,7 \%^{\mathrm{b}}$ \\
\hline Wrist length/height & $>11 \%$ & $0 \%$ & $25,0 \pm 6,3 \%^{b}$ \\
\hline
\end{tabular}

Note. ${ }^{a}$ the differences are significant, ${ }^{b}$ the differences are highly significant 
Table 2 The prevalence of positive tests for arachnodactyly in individuals with frequent post-exercise musculoskeletal disorders in comparison with CG

\begin{tabular}{|c|c|c|c|}
\hline & Diagnostic Values of CTD & $\begin{array}{l}\text { Comparison group } \\
n=36\end{array}$ & $\begin{array}{l}\text { Persons with frequent post-exercise } \\
\text { musculoskeletal disorders } n=48\end{array}$ \\
\hline Wrist test & positive & $8,3 \pm 4,5 \%$ & $37,5 \pm 6,9 \%^{a}$ \\
\hline Thumb test & positive & $0 \%$ & $37,5 \pm 6,9 \%^{a}$ \\
\hline The length of the middle finger & $>10 \mathrm{~cm}$ & $0 \%$ & $43,8 \pm 7,2 \%^{\mathrm{a}}$ \\
\hline
\end{tabular}

Note: ${ }^{\text {athe }}$ differences are highly significant

Table 3 Osteo-articular signs in individuals with frequent postexercise musculoskeletal disorders in comparison with CG

\begin{tabular}{|c|c|c|}
\hline $\begin{array}{l}\text { Osteo-articular } \\
\text { signs of CTD }\end{array}$ & $\begin{array}{l}\text { Comparison } \\
\text { group } \\
n=36\end{array}$ & $\begin{array}{l}\text { Persons with frequent post- } \\
\text { exercise musculoskeletal } \\
\text { disorders } n=48\end{array}$ \\
\hline Scoliosis & $41,6 \pm 8,2 \%$ & $43,8 \pm 7,2 \%$ \\
\hline Kyphosis & $8,3 \pm 4,5 \%$ & $75,0 \pm 6,3 \% * *$ \\
\hline Kyphoscoliosis & $0 \%$ & $25,0 \pm 6,3 \%^{* *}$ \\
\hline «Flat» back & $0 \%$ & $6,3 \pm 3,5 \%$ \\
\hline $\begin{array}{l}\text { Shoulder blades' } \\
\text { asymmetry }\end{array}$ & $0 \%$ & $50,0 \pm 7,2 \% * *$ \\
\hline Shoulder asymmetry & $25,0 \pm 7,2 \%$ & $87,5 \pm 4,8 \%{ }^{* *}$ \\
\hline Pelvic bones' asymmetry & $0 \%$ & $50,0 \pm 7,2 \%^{* *}$ \\
\hline $\begin{array}{l}\text { Pterygoid shoulder } \\
\text { blades }\end{array}$ & $8,3 \pm 4,5 \%$ & $12,5 \pm 4,8 \%$ \\
\hline $\begin{array}{l}\text { Infundibular chest } \\
\text { deformity }\end{array}$ & $0 \%$ & $12,5 \pm 4,8 \%^{\mathrm{a}}$ \\
\hline $\begin{array}{l}\text { Keel-shaped chest } \\
\text { deformity }\end{array}$ & $0 \%$ & $12,5 \pm 4,8 \%^{a}$ \\
\hline Flatfoot & $50,0 \pm 8,3 \%$ & $43,8 \pm 7,2 \%$ \\
\hline Feet valgus installation & $8,3 \pm 4,5 \%$ & $43,8 \pm 7,2 \% * *$ \\
\hline X- and O-shaped legs & $0 \%$ & $50,0 \pm 7,2 \%^{* *}$ \\
\hline $\begin{array}{l}\text { Macrodactyly of the first } \\
\text { toe }\end{array}$ & $0 \%$ & $31,3 \pm 6,7 \% * *$ \\
\hline Pain in the spine & $25,0 \pm 7,2 \%$ & $100 \% * *$ \\
\hline Joint hypermobility & $0 \%$ & $62,5 \pm 6,9 \%^{* *}$ \\
\hline "Crunch" in the joints & $25,0 \pm 7,2 \%$ & $62,5 \pm 6,9 \% * *$ \\
\hline $\begin{array}{l}\text { "Crunch" in the } \\
\text { temporomandibular joint }\end{array}$ & $16,6 \pm 6,2 \%$ & $50,0 \pm 7,2 \% * *$ \\
\hline Arthralgia & $0 \%$ & $50,0 \pm 7,2 \% * *$ \\
\hline $\begin{array}{l}\text { Joint dislocations and } \\
\text { subluxations }\end{array}$ & $0 \%$ & $12,5 \pm 4,8 \%^{a}$ \\
\hline $\begin{array}{l}\text { Ligament sprains and } \\
\text { ruptures }\end{array}$ & $25,0 \pm 7,2 \%$ & $100 \% * *$ \\
\hline Bone fractures & $8,3 \pm 4,5 \%$ & $50,0 \pm 7,2 \% * *$ \\
\hline Narrow facial skeleton & $0 \%$ & $12,5 \pm 4,8 \%^{\mathrm{a}}$ \\
\hline Wide-set eyes & $0 \%$ & $6,3 \pm 3,5 \%$ \\
\hline Gothic high palate & $0 \%$ & $62,5 \pm 6,9 \% * *$ \\
\hline Malocclusion & $0 \%$ & $18,8 \pm 5,6 \%^{\mathrm{a}}$ \\
\hline
\end{tabular}

${ }^{a}$ statistically significant differences

**the differences are highly significant based studies [30, 33, 34]. It is important to further consider the phenotypic manifestations of CTD in the form of appropriate clinical syndromes. Most often this pathology is characterized by osteoarticular changes (Table 3) [3, 4].

One of the important morphological signs of CTD, characterizing the involvement of the skeletal system, is dolichostenomelia (lengthening of the extremities), which is determined by measuring the tubular bones and estimating indexes [35]. Our study has shown that up to $63 \%$ of patients with frequent post-exercise musculoskeletal disorders present with a Quetelet index (BMI) $\leq 25,31 \%$ with Vargi Index $<1.7,25 \%$ with Pigne Index $\geq 30$ and $19 \%$ with Verveka Index between 1.26 and 1.35. Limb changes in CTD often present with arachnodactyly (long, thin, "spider" fingers) [36], which, according to our study along with muscular and vascular symptoms was significantly more common in patients with frequent muscular-skeletal disorders. These findings hint towards presence undifferentiated connective tissue disease (UCTD) in the experimental group.

Ectodermal manifestations (Table 4) in examined patients were characterized by a more frequent presence of thin skin with a well-visible network of subcutaneous vasculature located on the chest, back and limbs. In a significant percentage of cases, manifestations of the vascular syndrome were seen. This is an important aspect, due to the presence of vasculature pathology in many severe connective tissue diseases, which may help early detection of underlying pathology [37-39].

Consistent with existing data, many patients with frequent post-exercise musculoskeletal disorders have shown to have specific gastrointestinal symptoms. Therefore, gastrointestinal tract pathology was significantly more often detected in the experimental group in the form of biliary dyskinesia, failure of stomach cardia and gastroesophageal reflux syndrome (Table 5). This is characteristic of many underlying connective tissue diseases, such as eosinophilic disorders [40], gastrointestinal vasculitis [41], Ehlers-Danlos syndromes [42], and others [43, 44].

The presence of the discussed diagnostically significant morphological signs of CTD in humans is a pathognomonic predictor of high susceptibility to frequent post- 
Table 4 Ectodermal signs in individuals with frequent postexercise musculoskeletal disorders in comparison with CG

\begin{tabular}{|c|c|c|}
\hline Signs of CTD & $\begin{array}{l}\text { Comparison } \\
\text { group } \\
n=36\end{array}$ & $\begin{array}{l}\text { Persons with frequent post- } \\
\text { exercise musculoskeletal } \\
\text { disorders } n=48\end{array}$ \\
\hline Thin skin & $8,3 \pm 4,5 \%$ & $25,0 \pm 6,3 \%^{a}$ \\
\hline Nosebleeds & $8,3 \pm 4,5 \%$ & $12,5 \pm 4,8 \%$ \\
\hline Keloid scars & $0 \%$ & $25,0 \pm 6,3 \%^{a}$ \\
\hline Petechia & $0 \%$ & $18,8 \pm 5,6 \%^{a}$ \\
\hline $\begin{array}{l}\text { Skin hyperpigmentation } \\
\text { above the spine }\end{array}$ & $0 \%$ & $12,5 \pm 4,8 \%^{a}$ \\
\hline Atrophic striae & $8,3 \pm 4,5 \%$ & $37,5 \pm 6,9 \% * *$ \\
\hline Teleangiectasia & $0 \%$ & $12,5 \pm 4,8 \%^{a}$ \\
\hline $\begin{array}{l}\text { Nails (soft/fragile/ } \\
\text { exfoliated) }\end{array}$ & $33,3 \pm 7,9 \%$ & $87,5 \pm 4,8 \% * *$ \\
\hline $\begin{array}{l}\text { Hair (thin/brittle/areas of } \\
\text { alopecia) }\end{array}$ & $8,3 \pm 4,5 \%$ & $81,3 \pm 5,6 \% * *$ \\
\hline $\begin{array}{l}\text { Auricles (soft/rolled into a } \\
\text { tube) }\end{array}$ & $8,3 \pm 4,5 \%$ & $62,5 \pm 6,9 \%^{* *}$ \\
\hline Myotonic syndrome & $8,3 \pm 4,5 \%$ & $18,8 \pm 5,6 \%$ \\
\hline $\begin{array}{l}\text { Diastasis of rectus } \\
\text { abdominis muscle }\end{array}$ & $0 \%$ & $18,8 \pm 5,6 \%^{a}$ \\
\hline Hernia & $0 \%$ & $12,5 \pm 4,8 \%^{\mathrm{a}}$ \\
\hline
\end{tabular}

${ }^{\mathrm{a}}$ statistically significant differences

**the differences are highly significant

Table $\mathbf{5}$ Internal signs in individuals with frequent post-exercise musculoskeletal disorders in comparison with CG

\begin{tabular}{|c|c|c|}
\hline Signs of CTD & $\begin{array}{l}\text { Comparison } \\
\text { group } \\
n=36\end{array}$ & $\begin{array}{l}\text { Persons with frequent post- } \\
\text { exercise musculoskeletal disor- } \\
\text { ders } n=48\end{array}$ \\
\hline $\begin{array}{l}\text { Mitral valve } \\
\text { prolapse }\end{array}$ & $8,3 \pm 4,5 \%$ & $25,0 \pm 6,3 \%^{a}$ \\
\hline Vascular dystonia & $41,6 \pm 8,2 \%$ & $75,0 \pm 6,3 \%^{a}$ \\
\hline Pulse, beats/min & $67,13 \pm 5,62$ & $78,63 \pm 6,53^{a}$ \\
\hline $\begin{array}{l}\text { Systolic blood } \\
\text { pressure }\end{array}$ & $117,9 \pm 4,51$ & $108,3 \pm 6,12^{\mathrm{a}}$ \\
\hline $\begin{array}{l}\text { Diastolic blood } \\
\text { pressure }\end{array}$ & $72,66 \pm 6,71$ & $69,3 \pm 4,58$ \\
\hline $\begin{array}{l}\text { Lower extremities' } \\
\text { varicose veins }\end{array}$ & $0 \%$ & $56,3 \pm 7,2 \%^{b}$ \\
\hline Hemorrhoids & $8,3 \pm 4,5 \%$ & $56,3 \pm 7,2 \%^{b}$ \\
\hline Average myopia & $58,3 \pm 8,2 \%$ & $75,0 \pm 6,3 \%^{a}$ \\
\hline Astigmatism & $16,6 \pm 6,2 \%$ & $12,5 \pm 4,8 \%$ \\
\hline Biliary dyskinesia & $16,6 \pm 6,2 \%$ & $62,5 \pm 6,9 \%^{b}$ \\
\hline $\begin{array}{l}\text { Gastroesophageal } \\
\text { reflux }\end{array}$ & $8,3 \pm 4,5 \%$ & $68,8 \pm 6,7 \%^{b}$ \\
\hline $\begin{array}{l}\text { Chronic } \\
\text { esophagitis }\end{array}$ & $0 \%$ & $68,8 \pm 6,7 \%^{b}$ \\
\hline $\begin{array}{l}\text { Asthenic } \\
\text { syndrome }\end{array}$ & $8,3 \pm 4,5 \%$ & $75,0 \pm 6,3 \%^{b}$ \\
\hline
\end{tabular}

Table 6 Ranking of the most common morphological signs depending on their clinical significance in individuals with frequent post-exercise musculoskeletal disorders based on the scale of Kadurina T.I. and Abbamukova L.N

\begin{tabular}{|c|c|c|}
\hline Signs of CTD & $\begin{array}{l}\text { Prevalence, } \\
\%\end{array}$ & $\begin{array}{l}\text { Clinical significance } \\
\text { grade (Kadurina \& } \\
\text { Abbamukova Scale) }\end{array}$ \\
\hline Quetelet Index $\leq 25$ & $62,5 \pm 6,9 \%$ & 2 \\
\hline Kyphotic spinal deformation & $75,0 \pm 6,3 \%$ & 4 \\
\hline Shoulder asymmetry & $87,5 \pm 4,8 \%$ & 2 \\
\hline Shoulder blade asymmetry & $50,0 \pm 7,2 \%$ & 2 \\
\hline Asymmetry of the pelvic bones & $50,0 \pm 7,2 \%$ & 2 \\
\hline X- and O-shaped legs & $50,0 \pm 7,2 \%$ & 3 \\
\hline Pain in the spine & $100 \%$ & 4 \\
\hline Joint hypermobility moderate & $62,5 \pm 6,9 \%$ & 3 \\
\hline Gothic high palate & $62,5 \pm 6,9 \%$ & 3 \\
\hline «Crunch» in the joints & $62,5 \pm 6,9 \%$ & 2 \\
\hline $\begin{array}{l}\text { "Crunch" in the } \\
\text { temporomandibular joint }\end{array}$ & $50,0 \pm 7,2 \%$ & 4 \\
\hline Nails (soft/ brittle/exfoliated) & $87,5 \pm 4,8 \%$ & 2 \\
\hline Hair (thin/brittle/areas of alopecia) & $81,3 \pm 5,6 \%$ & 2 \\
\hline Auricles (soft/rolled into a tube) & $62,5 \pm 6,9 \%$ & 3 \\
\hline Vascular dystonia & $75,0 \pm 6,3 \%$ & 2 \\
\hline $\begin{array}{l}\text { Varicose veins of the lower } \\
\text { extremities }\end{array}$ & $56,3 \pm 7,2 \%$ & 3 \\
\hline Hemorrhoids & $56,3 \pm 7,2 \%$ & 3 \\
\hline Myopia of an average degree & $75,0 \pm 6,3 \%$ & 3 \\
\hline Biliary dyskinesia & $62,5 \pm 6,9 \%$ & 2 \\
\hline Gastroesophageal reflux & $68,8 \pm 6,7 \%$ & 2 \\
\hline Chronic esophagitis & $68,8 \pm 6,7 \%$ & 2 \\
\hline Asthenic syndrome & $75,0 \pm 6,3 \%$ & 4 \\
\hline
\end{tabular}

exercise musculoskeletal disorders and requires compliance with additional therapeutic and preventive recommendations. Our study showed that surveying and anthropomorphic evaluation has allowed to determine predictors of high predisposition to frequent postexercise musculoskeletal disorders. It is important to properly address these symptoms and anthropomorphic presentations in order to build a personalized approach to physical exercise regimen and lifestyle changes in this group of patients. Improper physical training in patients with CTD can lead to significant health problems. More so, early screening for CTD can help determine a large specter of predisposed diseases.

Osteopathy is recommended as part of CTD treatment. This method, restoring impaired structuralanatomical relationships between various organs and parts of the body, contributes to the normalization of body functions [45]. Regularly conducted courses of osteopathy improve reflex activity and metabolic 
processes, leading to strengthening of connective tissue [46]. Further research should expand upon these findings, forming a standardized approach to early diagnosis of CTD in adolescents.

\section{Conclusion}

All patients with frequent post-exercise musculoskeletal disorders showed signs of CTD. The analysis of the morphological prevalence depending on clinical significance allowed us to determine pathognomonic predictors of high predisposition to injuries. Their early detection can promote the timely appointment of adequate physical activity regimen and therapy of the underlying cause. Based on our research results, we recommend proper evaluation of patients with frequent post-exercise musculoskeletal disorders, as this may be the only symptom of an underlying connective tissue disorder.

\section{Supplementary information}

Supplementary information accompanies this paper at https://doi.org/10. 1186/s12891-020-03698-0.

\section{Additional file 1.}

Additional file 2.

\section{Abbreviation}

CTD: Connective tissue dysplasia

\section{Acknowledgements}

Not applicable.

\section{Financial disclosure}

The authors declare no relevant financial interests or financial conflicts related to the material in the manuscript.

\section{Authors' contributions}

$V N, M V, A D, C Y$ conducted the clinical research and modeling and development of the project. AA, MA, EE, SM gathered the methodology, developed the evaluation forms and conducted patient monitoring. NA, MY, SM interpreted the raw data and performed statistical analysis. MY, VN, MV, MA, CY prepared the manuscript and revisions. All authors reviewed the final manuscript. The author(s) read and approved the final manuscript.

\section{Funding}

There was no funding/support for this study.

\section{Availability of data and materials}

The datasets used during the current study are available from the corresponding author on reasonable request.

\section{Ethics approval and consent to participate}

Current research study was approved by the Ethics Committee of First Moscow State Medical University named after I.M.Sechenov (Sechenov University) under protocol № 08-19 at 05.06.2019. Patient Consent: Informed written consent was obtained from the participants included in this study.

\section{Consent for publication}

Informed written consent to publication of research was obtained from the participants included in this study.

\section{Competing interests}

The authors declare no conflicts of interest in the writing and preparation of this article.

\section{Author details}

${ }^{1}$ First Moscow State Medical University named after I.M.Sechenov (Sechenov University), st. Trubetskaya, 8, bld. 2, 119991 Moscow, Russia. ${ }^{2}$ Lomonosov Moscow State University, Leninskie Gory, 1, 119991 Moscow, Russia. ${ }^{3}$ European Osteopathic Clinical Center of the Moscow branch of the "Medical Academy of Osteopathic Education", Gavanskaya St., 4, block 2, 199106 St. Petersburg, Russia. Institute for Regenerative Medicine, Sechenov University, st. Trubetskaya, 8, bld. 2, 119991 Moscow, Russia.

Received: 6 May 2020 Accepted: 1 October 2020

Published online: 08 October 2020

\section{References}

1. Wojtys EM. Preventing sports injuries. Sports Health. 2019;11(1):16-7.

2. Kogan EA, Nikolenko VN, Zanozin AS, Demura TA, Kolosovsky DY. Syndrome of undifferentiated connective tissue dysplasia in combination with hereditary thrombophilia as the cause of primary female infertility, Med J North Caucasus. 2016:11(2-2):323-6.

3. Styazkina SN, Knyazev AD, Minakhanov II. Dysplasia of the connective tissue in modern clinical practice. Modern Innov. 2016:5(7):57-64.

4. Mosca M, Tani C, Vagnani S, Bombardieri S. The diagnosis and classification of undifferentiated connective tissue diseases. J Autoimmun. 2014;48-49:50-2.

5. Capuano A, Bucciotti F, Farwell KD, Tippin Davis B, Mroske C, Hulick PJ, Weissman SM, Gao Q, Spessotto P, Colombatti A, Doliana R. Diagnostic exome sequencing identifies a novel gene, EMILIN1, associated with autosomal-dominant hereditary connective tissue disease. Hum Mutat. 2016; 37(1):84-97

6. Alazami AM, Al-Qattan SM, Faqeih E, Alhashem A, Alshammari M, Alzahrani F, Al-Dosari MS, Patel N, Alsagheir A, Binabbas B, Alzaidan H, Alsiddiky A, Alharbi N, Alfadhel M, Kentab A, Daza RM, Kircher M, Shendure J, Hashem M, Alshahrani S, Rahbeeni Z, Khalifa O, Shaheen R, Alkuraya FS. Expanding the clinical and genetic heterogeneity of hereditary disorders of connective tissue. Hum Genet. 2016 May;135(5):525-40.

7. Ben SM, Repin NB. Clinical diagnosis of undifferentiated connective tissue dysplasia. Russ Med Biol J. 2016;24(4):164-72. Academician IP Pavlova.

8. Sung YK, Chung L. Connective tissue disease-associated pulmonary arterial hypertension. Rheum Dis Clin N Am. 2015:41(2):295-313.

9. Arroyo-Avila M, Vila LM. Cardiac tamponade in a patient with mixed connective tissue disease. J Clin Rheumatol. 2015;1(21):42-5.

10. Kadurina TI, Gnusaev SF, Abbakumova LN, Alimova IL, Antonova NS, Apenchenko Yu S, Arsentyev VG, Dakuko AN, Koptseva AV, Krasnova EE, Kudinova EG, Ivanova II, Ivanova IL, Kuznetsova LV, Lisitsina SV, Mambetova AM, Murga W, Nikolaeva EA, Plotnikova OV, Sertakova AV. Hereditary and multifactorial disorders of the connective tissue in children diagnostic algorithms. The tactics of reference for the draft Russian recommendations was developed by a committee of experts of the pediatric group "connective tissue dysplasia" at the Russian scientific community of physicians. Med Bull North Caucasus. 2015;10(1):5-35.

11. Martynov Al, Nechaeva GI, Akatova EV, Vershinina MV, Viktorova IA, Goltsova LG, Gromova OA, Delov RA, Drokina OV, Druk IV, Dubiley GS, Ivanova DS, Ivanova IL, Kalinina IY, Kononova NY, Kudinova EG, Lalov YV, Lisichenko OV, Loginova EN, Lyalukova YA, et al. Clinical recommendations of the Russian scientific medical society of therapists for the diagnosis, treatment and rehabilitation of patients with connective tissue dysplasia (first revision). Med Bull North Caucasus. 2018;13(1-2):137-209.

12. Castori $M$, Castori $M$, Tinkle $B$, Levy $H$, et al. A framework for the classification of joint hypermobility and related conditions. Am J Med Genet C Semin Med Genet. 2017:175C:148-57.

13. Haller G, Haller G, Zabriskie H, Spehar S, et al. Lack of joint hypermobility increases the risk of surgery in adolescent idiopathic scoliosis. J Pediatr Orthop B. 2018:27(2):152-8.

14. Scheper MC, de Vries JE, Verbunt J, Engelbert RH. Chronic pain in hypermobility syndrome and Ehlers-Danlos syndrome (hypermobility type): it is a challenge. J Pain Res. 2015;8:591-601. https://doi.org/10.2147/JPR. S64251. eCollection 2015. Review.

15. Dangin A, Tardy N, Wettstein M, May O, Bonin N. Microinstability of the hip: a review. Orthop Traumatol Surg Res. 2016;102(8S):S301-9. https://doi.org/ 10.1016/j.otsr.2016.09.002. Epub 2016 Oct 12. Review.

16. Akimova AV, Mironov VA, Gagiev W, Tarasova EV, Palabugina PA, Khusainova DF, Talankina AA. Features of the clinic and autonomic 
regulation of sinus rhythm of the heart in individuals with undifferentiated connective tissue dysplasia. Bull Ural Med Acad Sci. 2017;14(4):315-24.

17. Arseni L, Lombardi A, Orioli D. From Structure to Phenotype: Impact of Collagen Alterations on Human Health. Int J Mol Sci. 2018;19(5). https://doi. org/10.3390/ijms19051407. Review.

18. Martynov Al, Nechaeva Gl, Akatova EV, Vershinina MV, Viktorova IA Gromova OA, Drokina OV, Druk IV, Dubiley GS, llinikh AA, Kudinova EG, Lisichenko OV, Loginova EN, Lyalyukova EA, Nagaeva TA, Nadey EV, Plotnikova OV, Ponomareva DA, Semenkin AA, Yu ST, et al. National recommendations of the Russian Scientific Medical Society of Therapists for the diagnosis, treatment and rehabilitation of patients with connective tissue dysplasia. Med J North Caucasus. 2016;11(1):2-76.

19. Castori M, Morlino S, Ghibellini G, Celletti C, Camerota F, Grammatico P. Connective tissue, Ehlers-Danlos syndrome(s), and head and cervical pain. Am J Med Genet C: Semin Med Genet. 2015;169(1):84-96.

20. Akimova AV, Tarasova EV, Chernikova LG. Clinical and phenotypic features of young people with undifferentiated connective tissue dysplasia. Med J MIA. 2018;1(92):63-7.

21. Kadurina Tl, Abbakumova LN. Assessment of the severity of undifferentiated connective tissue dysplasia in children. Med Bull North Caucasus. 2008;2:15-20.

22. Abbakumova LN, Arsentev VG, Gnusaev SF, Ivanova II, Kadurina TI, Trisvetova EL, Chemodanov W, Chukhlovina ML. Hereditary and multifactorial disorders of the connective tissue in children. Diagnostic algorithms. Tactics of reference. Russian recommendations. Pediatrician. 2016;7(2):5-39.

23. Zemtsovsky EV, Timofeev EV, Malev EG. Hereditary disorders (dysplasia) of connective tissue. Which of the two current national guidelines is preferred? Pediatrician. 2017:8(4):6-18.

24. Maruhno YI, Pyantkovsky AS. Dysplasia of the connective tissue in athletes. Med Prospects. 2012;17(1):114-8.

25. Chemodanov W, Krasnova EE, Gornakov IS. Constitutional typology, hereditary predisposition and connective tissue dysplasia in children: a history of study. Bull Ivanovo Med Acad. 2013;18(2):62-5

26. Nishimura RA, Otto CM, Bonow RO, Carabello BA, Erwin JP 3rd, Fleisher LA, Jneid H, Mack MJ, McLeod CJ, O'Gara PT, Rigolin VH, Sundt TM 3rd, Thompson A. AHA/ACC focused update of the 2014 AHA/ACC guideline for the Management of Patients with Valvular Heart Disease: a report of the American College of Cardiology/American Heart Association task force on clinical practice guidelines. Circulation. 2017;135(25):e1159-95. https://doi. org/10.1161/CIR.0000000000000503. Epub 2017 Mar 15. Review.

27. Nechaeva GI, Viktorova IA. Connective tissue dysplasia: terminology, diagnosis, patient management tactics, vol. 188. Omsk: LLC "Printing house Blanc"; 2007.

28. Keer $\mathrm{R}$, Simmonds J. Joint protection and physical rehabilitation of the adult with hypermobility syndrome. Curr Opin Rheumatol. 2011;23(2):131-6. https://doi.org/10.1097/BOR.0b013e328342d3af. Review.

29. Kumar B, Lenert $P$. Joint hypermobility syndrome: recognizing a commonly overlooked cause of chronic pain. Am J Med. 2017;130(6):640-7. https://doi. org/10.1016/j.amjmed.2017.02.013. Epub 2017 Mar 10. Review.

30. Shodikulova GZ. Special features of clinical and functional disorders in patients with undifferentiated connective tissue dysplasia. Eur Sci Rev. 2017; 17(3-4):72-4.

31. Palmer S, Bailey S, Barker L, Barney L, Elliott A. The effectiveness of therapeutic exercise for joint hypermobility syndrome: a systematic review. Physiotherapy. 2014;100(3):220-7. https://doi.org/10.1016/j.physio.2013.09. 002. Epub 2013 Oct 5. Review.

32. Toprak Celenay S, Ozer KD. Effects of spinal stabilization exercises in women with benign joint hypermobility syndrome: a randomized controlled trial. Rheumatol Int. 2017;37(9):1461-8. https://doi.org/10.1007/s00296-017-37136. Epub 2017 Mar 30

33. Kunabay K, Seidanova AB, Suinalieva AA. Psychovegetative, asthenic and cognitive impairment in connective tissue dysplasia: the choice of optimal therapy. Vestnik KazNMU. 2017;1(2):255-60.

34. Bergelson T, Mashin V, Belova L, Proshin A, Belova N, Abdulaev I. Neurological and psychological characteristics of children with connective tissue dysplasia. Clin Neurosci. 2017;1(Michaelmas):16-8.

35. Timofeev EV, Zaripov BI, Belousova TI, Vutrih EV, Reeva SV, Parfenova NN, Zemtsovsky EV. Phenotypic characteristics of young men and women depending on the type of constitution and low body weight. Pediatrician (St Petersburg). 2020;11(1):27-35.
36. Mukerji B, Hardin JG. Undifferentiated, Overlapping, and MixedConnective Tissue Diseases. Am J Med Sci. 1993;305(2):114-9.

37. Cavagna L, Codullo V, Ghio S, Scirè CA, Guzzafame E, Scelsi L, Caporali R. Undiagnosed connective tissue diseases: high prevalence in pulmonary arterial hypertension patients. Medicine. 2016;95(39).

38. Kasama T, Maeoka A, Oguro N. Clinical features of neuropsychiatric syndromes in systemic lupus erythematosus and other connective tissue diseases. Clin Med Insights. 2016;9 CMAMD-S37477.

39. Kim ST, Brinjikji W, Kallmes DF. Prevalence of intracranial aneurysms in patients with connective tissue diseases: a retrospective study. Am J Neuroradiol. 2016:37(8):1422-6.

40. Lecouffe-Desprets M, Groh M, Bour B, Le Jeunne C, Puechal X. Eosinophilic gastrointestinal disorders associated with autoimmune connective tissue disease. Joint Bone Spine. 2016;83(5):479-84.

41. Li M, Luo W, Li P, Luo J, Huo J, Li Y. Connective tissue disease-induced gastrointestinal vasculitis: a clinical analysis of 14 cases. Int J Clin Exp Pathol. 2016;9(2):2091-8.

42. Fikree A, Chelimsky G, Collins H, Kovacic K, Aziz Q. Gastrointestinal involvement in the Ehlers-Danlos syndromes. Am J Med Genet Part C. 2017; 175(1):181-7.

43. Arora M, Bagi P, Strongin A, Heimall J, Zhao X, Lawrence MG, Kleiner DE. Gastrointestinal manifestations of STAT3-deficient hyper-lgE syndrome. J Clin Immunol. 2017;37(7):695-700.

44. Shimoda S, Chong Y, Akahoshi M, Niiro H, Tsukamoto H. Hepatic and gastrointestinal manifestations in rheumatic and connective tissue diseases. J Gen Fam Med. 2016:17(2):132-7.

45. Slattengren AH, Nissly T, Blustin J, Bader A, Westfall E. Best uses of osteopathic manipulation. J Fam Pract. 2017;66(12):743-7 Review.

46. American Osteopathic Association Guidelines for Osteopathic Manipulative Treatment (OMT) for Patients With Low Back Pain. Task force on the low Back pain clinical practice guidelines. J Am Osteopath Assoc. 2016;116(8): 536-49. https://doi.org/10.7556/jaoa.2016.107.

\section{Publisher's Note}

Springer Nature remains neutral with regard to jurisdictional claims in published maps and institutional affiliations.

Ready to submit your research? Choose BMC and benefit from

- fast, convenient online submission

- thorough peer review by experienced researchers in your field

- rapid publication on acceptance

- support for research data, including large and complex data types

- gold Open Access which fosters wider collaboration and increased citations

- maximum visibility for your research: over $100 \mathrm{M}$ website views per year

At $\mathrm{BMC}$, research is always in progress.

Learn more biomedcentral.com/submission 